\title{
Evaluation of the rheumatoid arthritis susceptibility loci HLA-DRB1, PTPN22, OLIG3/TNFAIP3, STAT4 and TRAF1/C5 in an inception cohort
}

\author{
Ann W Morgan*1, James I Robinson'1, Philip G Conaghan'1, Stephen G Martin'1, Elizabeth MA Hensor1, \\ Michael D Morgan'1, Lori Steiner², Henry A Erlich², Hock-Chye Gooi³, Anne Barton4, Jane Worthington4, Paul Emery' \\ for UKRAG Consortium and the YEAR Consortium
}

\begin{abstract}
Introduction: This study investigated five confirmed rheumatoid arthritis (RA) susceptibility genes/loci (HLA-DRB1, PTPN22, STAT4, OLIG3/TNFAIP3 and TRAF1/C5) for association with susceptibility and severity in an inception cohort.

Methods: The magnitude of association for each genotype was assessed in 1,046 RA subjects from the Yorkshire Early RA cohort and in 5,968 healthy UK controls. Additional exploratory subanalyses were undertaken in subgroups defined by autoantibody status (rheumatoid factor and anti-cyclic citrullinated peptide) or disease severity (baseline articular erosions, Health Assessment Questionnaire (HAQ) score and swollen joint count (SJC)).

Results: In the total RA inception cohort, the HLA-DRB1 shared epitope (per-allele odds ratio $(\mathrm{OR})=2.1$, trend $P<$ 0.0001), PTPN22 (per-allele $\mathrm{OR}=1.5$, trend $P<0.0001$ ), OLIG3/TNFAIP3 locus (per-allele $\mathrm{OR}=1.2$, trend $P=0.009$ ) and TRAF1/C5 locus (per-allele OR $=1.1$, trend $P=0.04$ ) were associated with RA. The magnitude of association for these loci was increased in those patients who were autoantibody-positive. PTPN22 was associated with autoantibody-negative RA (per-allele $\mathrm{OR}=1.3$, trend $P=0.04$ ). There was no evidence of association between these five genetic loci and baseline erosions or SJC in the total RA cohort, after adjustment for symptom duration. TRAF1/C5 was significantly associated with baseline $\mathrm{HAQ}$, however, following adjustment for symptom duration ( $P$ trend $=0.03$ ).

Conclusions: These findings support the mounting evidence that different genetic loci are associated with autoantibody-positive and autoantibody-negative RA, possibly suggesting that many of the genes identified to date are associated with autoantibody production. Additional studies with a specific focus on autoantibody-negative RA will be needed to identify the genes predisposing to this RA subgroup. The TRAF1/C5 locus in particular warrants further investigation in RA as a potential disease severity locus.
\end{abstract}

\section{Introduction}

Rheumatoid arthritis (RA) [MIM 180300] is a phenotypically heterogeneous, chronic destructive inflammatory disease of synovial joints, with an estimated prevalence of $0.8 \%$ in the UK [1]. A strong genetic component has been determined with heritability estimates of 50 to $60 \%$ from

* Correspondence: a.w.morgan@leeds.ac.uk

1 NIHR - Leeds Musculoskeletal Biomedical Research Unit, Leeds Institute of Molecular Medicine, University of Leeds, Chapel Allerton Hospital, Chapeltown Road, Leeds LS7 4SA, UK

Full list of author information is available at the end of the article twin studies, with up to an additional $50 \%$ contribution from environmental and/or physiological risk factors [2]. Approximately $40 \%$ of genetic susceptibility to RA is accounted for by the HLA-DRB1 alleles encoding the shared epitope (SE), the major RA susceptibility locus [3], together with the protein tyrosine phosphatase nonreceptor 22 gene (PTPN22), a second susceptibility gene confirmed in populations of northern European ancestry [4]. Recent genome-wide association studies and candidate gene studies in RA have been highly successful in both the confirmation of known genetic associations and 
in highlighting new loci/immunological pathways that warrant further investigation [5]. The present study focuses on five confirmed RA susceptibility genes/loci HLA-DRB1 (6p21), PTPN22 (1p13), OLIG3/TNFAIP3 (6q23), STAT4 (2q32) and TRAF1/C5 (9q33) - that are associated with RA with low-to-moderate risk in UK patients [6-8]. Some of these loci have been replicated in other Caucasian populations of northern European descent (reviewed in [5,9]), although only HLA-DRB1 SE and STAT4 have been confirmed in Asian populations [10-12].

RA is characterised by the presence of autoantibodies (rheumatoid factor (RF) and cyclic citrullinated peptide (CCP) antibodies) in a significant majority of patients. Many of the RA susceptibility genes identified to date appear to only be significant in the autoantibody-positive cohorts, although this may be secondary to the increased statistical power in this more prevalent patient subgroup [13]. If confirmed, this observation may suggest that these loci are influencing susceptibility to autoantibody production, perhaps through the loss of self-tolerance, thus explaining their association with multiple autoimmune disorders. The challenge over the next few years will be to identify whether these genes also influence the inflammatory process in RA per se. Unravelling the stage in the disease process in which these genes exert their maximum influence on RA pathogenesis will be necessary to fully unveil their clinical significance and reveal those pathways that are potential therapeutic targets or may become clinically useful biomarkers.

In the present study we sought to identify which parts of the RA pathway were affected by these susceptibility genes by studying an RA inception cohort from the UK. The Yorkshire Early Arthritis Register (YEAR) Consortium has made a considerable effort to review all patients presenting with early inflammatory symptoms within the community through the establishment of a rapid access system. This enables the full spectrum of RA to be studied. Confirmation of association in this cohort of newly diagnosed RA would support a contribution of these loci to RA susceptibility per se rather than disease persistence and severity, which potentially confound assessment of genetic susceptibility in cross-sectional secondary care cohorts. Further analyses, albeit at reduced statistical power, would determine whether the association is observed within both the autoantibody-positive (RF or $\mathrm{CCP}$ ) and the autoantibody-negative (RF or CCP) subgroups, to determine whether the primary association was with autoantibody-positive disease. These two antibodies are highly correlated and much larger cohorts would be required to tease out antibody-specific effects.

We then sought to examine the influence of these loci on disease severity. Analysis of RA severity following the initiation of therapy is fraught with many difficulties since the physician's choice of medication, dose prescribed, toxicities, co-morbidities and psychosocial factors may all influence treatment outcome and persistence of inflammation. We therefore took advantage of our rapid access referral system to assess the influence of these loci on objective markers of joint inflammation (swollen joint count (SJC)), function (Health Assessment Questionnaire (HAQ)) and a measure of articular damage (erosions on plain radiographs of the hands and feet) at RA diagnosis. Although these secondary severity analyses would be of lower statistical power and require replication, we propose that any positive results would reveal those pathophysiological pathways that warrant further investigation to see whether they can be exploited as potential therapeutic targets and prognostic and/or predictive biomarkers that may ultimately guide therapeutic decisions.

\section{Materials and methods Sample collections}

The YEAR network made a considerable effort to review all patients presenting with early inflammatory joint symptoms to ensure that the full spectrum of established RA could be studied. All cases fulfilled the 1987 American College of Rheumatology classification criteria for RA $(\mathrm{n}=1,046)$, were Caucasian of Northern European descent, 18 years of age or older at disease onset and had a disease duration of less than 3 months (inception cohort). Comprehensive and standardised clinical documentation was undertaken for all patients at baseline. Radiographs of the hands and feet were obtained at presentation. The presence or absence of articular erosions, using standard clinical criteria, was documented by a radiologist at the treating hospital. Healthy controls $(\mathrm{n}=$ 5,968 ) were recruited from five centres in the UK, as described previously [8]. All participants were recruited after providing informed consent and the study was approved by the Multi-Centre Research Ethics Committee.

\section{Immunoassays}

RA cases were recruited from NHS Rheumatology Clinics and the IgM RF status was measured using standard nephelometric assays. Patients who had ever had a titre $\geq$ 40 units/ml were defined as RF-positive. The presence of IgG CCP antibodies was documented at a single time point for a proportion of the patients $(n=619)$, using the commercially available DIASTAT ${ }^{\mathrm{sm}}$ anti-CCP ELISA (Axis-Shield Diagnostics Limited, Kimbolton, UK) or the ELiA CCP kit on an ImmunoCAP 100 (Phadia AB, Uppsala, Sweden). Patients who had a titre $\geq 5.5$ units $/ \mathrm{ml}$ or $\geq$ $10 \mathrm{units} / \mathrm{ml}$ for the two assays, respectively, were defined as CCP-positive. 


\section{Genotyping}

$H L A-D R B 1 * 01-16$ types were determined at each centre using commercially available semi-automated PCR sequence-specific oligonucleotide probe typing techniques, as previously described [8]. In a subgroup of RA subjects, $H L A-D R B 1$ typing was undertaken using a research assay based on PCR sequence-specific oligonucleotide probe linear array technology, developed by Roche Molecular Systems, Inc. (Pleasanton, CA, USA). PCR products amplified with biotinylated primers were denatured and hybridised to an immobilised probe array. Labelled PCR products hybridised to specific probes were detected using streptavidin-horseradish peroxidase and a chromogenic substrate. The probe binding pattern for each sample was scanned and the HLA-DRB1 genotype was assigned by the inhouse software StripScan. The $H L A-D R B 1$ SE susceptibility sequences were defined as those encoding the amino acids LQKAA, LQRAA and LRRRA at positions $67,70,71,73$ and 74 in the third hypervariability region, and included $H L A-D R B 1 * 0101$, HLA-DRB1*0102, HLA-DRB1*0401, HLA-DRB1*0404, HLA-DRB1*0405, HLA-DRB1*0408 and HLA$D R B 1^{*} 1001$.

Genotyping of the PTPN22, OLIG3/TNFAIP3, STAT4 and TRAF1/C5 loci was undertaken using the Sequenom MassArray platform, as described previously [6-8]. Genotyping was undertaken sequentially and these samples comprised a subgroup of the RA cases recruited by the UK Rheumatoid Arthritis Genetics (UKRAG) Consortium. For each individual plex, only those DNA samples with $>90 \%$ success rate for all SNPs and those SNPs with $>95 \%$ success rates across all samples passed the quality control step and were included in subsequent analyses. For some samples, inadequate DNA was available to enable inclusion in all plexes for this study. Some additional PTPN22 typing was undertaken using multi-locus SNP genotyping, whereby PCR products were hybridised to a linear probe array panel, which was developed by Roche Molecular Systems, Inc. Duplicate genotyping data were available for PTPN22 for $>600$ samples that corresponded perfectly, thus validating the latter assay. For each of the four non-MHC loci, the most significantly associated SNP identified to date in the UK population was tested (PTPN22 [rs2476601], OLIG3/TNFAIP3 locus [rs6920220], STAT4 [rs7574865] and TRAF1/C5 locus [rs10760130]).

\section{Analysis}

Statistical analyses were performed using the SPSS 13.0 statistical package for Windows, (Chicago, IL, USA). Genotype frequencies were initially compared using $3 \times 2$ tables followed by a trend test, which performs well under either additive, dominant or recessive models. This is asymptotically equivalent to logistic or linear regression based on allele count $(0,1,2)$. Two-sided $P<0.05$ values are highlighted, although positive findings should be considered in light of the number of statistical tests undertaken and further studies in additional inception cohorts will be required to confirm these findings. The data were further stratified according to the presence of autoantibodies (RF and/or CCP). Subjects were grouped into autoantibody (RF or CCP)-positive and autoantibodynegative (RF and CCP) cohorts. Those individuals only positive for only a single antibody $\left(\mathrm{RF}^{+} \mathrm{CCP}^{-}\right.$and $\mathrm{RF}^{-}$ $\mathrm{CCP}^{+}$) were thus coded as autoantibody-positive. Where data were only available for a single antibody $(\mathrm{n}=445)$, those subjects were included in the autoantibody-positive or autoantibody-negative cohorts based on the data available. In the analysis of disease susceptibility, odds ratios (OR) and their 95\% confidence intervals were calculated; the per-allele ORs are shown unless otherwise stated. The severity analyses were undertaken in a subgroup of patients where the symptom duration was known and $<24$ months. Logistic (presence/absence of erosions) and linear regression (SJC, HAQ) were used to undertake trend tests of association, which were adjusted for symptom duration.

\section{Results}

The aim of the current study was to determine whether the previously reported RA susceptibility genes/loci (HLA-DRB1, PTPN22, OLIG3/TNFAIP3, STAT4 and TRAF1/C5) were associated with RA in an inception cohort. Additional exploratory subanalyses were undertaken to explore whether any positive findings were associated with a specific subgroup defined by autoantibody status or disease severity (baseline articular erosions, SJC and $\mathrm{HAQ}$ ).

\section{Characteristics of the RA patients and controls}

The RA cohort comprised 1,046 early RA patients, of whom $67 \%$ were female, $65 \%$ were RF-positive $(\mathrm{n}=970)$, $63 \%$ were anti-CCP-positive $(\mathrm{n}=619)$ and $70 \%$ of 968 subjects were $H L A-D R B 1$ SE-positive. The disease characteristics of the total RA cohort and the autoantibodypositive (RF or CCP) and autoantibody-negative (RF and CCP) cohorts are presented in Table 1.

\section{Association of HLA-DRB1 SE, PTPN22, OLIG3/TNFAIP3, STAT4 and TRAF1/C5 with RA susceptibility}

In the total RA inception cohort ( $\mathrm{n}=1,046)$, an initial model-free analysis of genotype frequencies was performed by undertaking a $3 \times 2$ analysis. The global $P$ values for each genetic locus are as follows: HLA-DRB1 SE alleles, $P<1 \times 10^{-6}(\mathrm{n}=968)$; PTPN22, $P=2 \times 10^{-6}(\mathrm{n}=$ 855); OLIG3/TNFAIP3, $P=0.030(\mathrm{n}=810)$; STAT4, $P=$ $0.035(\mathrm{n}=767)$; and TRAF1/C5, $P=0.041(\mathrm{n}=763)$. 
Table 1: Clinical characteristics of rheumatoid arthritis cases

\begin{tabular}{|c|c|c|c|c|c|c|}
\hline & \multicolumn{2}{|c|}{ Total RA cohort $(n=1,046)$} & \multicolumn{2}{|c|}{$\begin{array}{l}\text { Autoantibody-positive RA } \\
\qquad(n=692)\end{array}$} & \multicolumn{2}{|c|}{$\begin{array}{l}\text { Autoantibody-negative RA } \\
\qquad(n=325)\end{array}$} \\
\hline Age (years) & 926 & $59(14)$ & 411 & $57(13)$ & 183 & $60(14)$ \\
\hline $\begin{array}{l}\text { Gender } \\
\text { (female) }\end{array}$ & 1046 & 702 (67\%) & 692 & $468(68 \%)$ & 325 & $210(65 \%)$ \\
\hline $\begin{array}{l}\text { Rheumatoid } \\
\text { factor-positive }\end{array}$ & 970 & $628(65 \%)$ & 667 & $628(94 \%)$ & $\mathrm{N} / \mathrm{A}$ & $\mathrm{N} / \mathrm{A}$ \\
\hline $\begin{array}{l}\text { Cyclic } \\
\text { citrullinated } \\
\text { peptide- } \\
\text { positive }\end{array}$ & 619 & $389(63 \%)$ & 445 & $389(87 \%)$ & $\mathrm{N} / \mathrm{A}$ & $\mathrm{N} / \mathrm{A}$ \\
\hline $\begin{array}{l}\text { Erosions at } \\
\text { baseline }^{a}\end{array}$ & 607 & $132(22 \%)$ & 421 & $95(23 \%)$ & 186 & $37(28 \%)$ \\
\hline $\begin{array}{l}\text { Swollen joint } \\
\text { count at } \\
\text { baseline }^{a}\end{array}$ & 648 & $\begin{array}{l}9.7(6.2 \text { to } \\
10.2)\end{array}$ & 447 & 9.3 (8.8 to 9.9 ) & 186 & $\begin{array}{l}10.8 \text { (9.8 to } \\
11.8)\end{array}$ \\
\hline $\begin{array}{l}\text { Health } \\
\text { Assessment } \\
\text { Questionnaire } \\
\text { at baseline }\end{array}$ & 648 & $\begin{array}{l}1.33(1.27 \text { to } \\
1.39)\end{array}$ & 447 & $\begin{array}{l}1.35(1.28 \text { to } \\
1.42)\end{array}$ & 186 & $\begin{array}{l}1.30(1.19 \text { to } \\
1.41)\end{array}$ \\
\hline
\end{tabular}

Data presented as mean (standard deviation), $n$ (\%) or mean (95\% confidence interval). N/A, not applicable; RA, rheumatoid arthritis.

asubgroup of individuals with documented symptom duration $<24$ months.

In subsequent analyses, trend tests were performed across all three genotypes; the ORs (95\% confidence intervals) shown are per copy of the HLA-DRB1 SE or per copy of the minor allele for the remaining loci (Table 2). Thus, HLA-DRB1 SE alleles (OR $=2.1$ (1.9 to 2.4), $P<$ $0.0001)$, PTPN22 (OR $=1.5$ (1.3 to 1.8$), P<0.0001)$, OLIG3/TNFAIP3 (OR $=1.2$ (1.0 to 1.4), $P=0.009$ ) and TRAF1/C5 (OR = 1.1 (1.0 to 1.3$), P=0.035$ ) were associated with RA. The magnitude of association for these loci was increased in those patients who were autoantibodypositive (HLA-DRB1 SE, OR $=2.9$ (2.5 to 3.3$), P<0.0001$; PTPN22, OR $=1.6$ (1.3 to 1.9$), P<0.0001 ;$ OLIG3/ TNFAIP3, OR $=1.3$ (1.1 to 1.5$), P<0.0001$; and TRAF1/ $C 5$, OR $=1.2$ (1.0 to 1.3), $P=0.043$ ), with weak evidence of association for STAT4 (OR $=1.2$ (1.0 to 1.4), $P=0.048$ ) in this subgroup. The size of the autoantibody-negative cohort was limited $(n=298)$, resulting in lower statistical power - although a significant association was observed with PTPN22 (OR = 1.3 (1.0 to 1.7$), P=0.039$ ). There was no evidence, however, of association for the HLA-DRB1 SE (OR $=1.1$ (0.9 to 1.4), $P=0.279$ ), or for the OLIG3/ TNFAIP3 (OR $=0.9$ (0.7 to 1.2$), P=0.578)$, STAT4 $(\mathrm{OR}=$ 1.1 (0.9 to 1.4 ), $P=0.266$ ) or TRAF1/C5 (OR $=1.1$ (0.9 to $1.3), P=0.392)$ loci in autoantibody-negative disease. A statistically significant difference in the genotype frequencies between the autoantibody-positive and autoan- tibody-negative cohorts was observed for $H L A-D R B 1 \mathrm{SE}$ (trend $P<0.001$ ) and OLIG3/TNFAIP3 (trend $P=0.008$ ), but not for $P T P N 22$ (trend $P=0.2$ ), STAT4 (trend $P=0.8$ ) or TRAF1/C5 (trend $P=0.6$ ).

\section{Association of HLA-DRB1 SE, PTPN22, OLIG3/TNFAIP3, STAT4} and TRAF1/C5 with RA severity

In view of the potential importance of symptom duration on disease severity measures at baseline, the severity analyses were undertaken in a subgroup of 666 individuals for whom the symptom duration had been recorded and was $<24$ months, to allow adjustment for symptom duration in the regression models.

Prevalent erosions were observed in $21.5 \%$ of 615 subjects at presentation and were associated with symptom duration $(P=0.011)$, but not with SJC $(P=0.96, \mathrm{n}=595)$, $\mathrm{RF}(P=0.21, \mathrm{n}=580)$ or CCP $(P=0.19, \mathrm{n}=428)$. Likewise, SJC was associated with symptom duration $(P<$ $0.001, \mathrm{n}=666)$, but not RF $(P=0.07, \mathrm{n}=623)$ or $\mathrm{CCP}(P=$ $0.15, \mathrm{n}=459)$. Finally, HAQ was associated with symptom duration $(P=0.001, \mathrm{n}=666)$ but not with $\mathrm{CCP}(P=$ $0.66, \mathrm{n}=480)$, with only a weak trend toward significance for RF $(P=0.05, \mathrm{n}=633)$. There was no evidence that HLA-DRB1 SE, PTPN22, OLIG3/TNFAIP3, STAT4 or $T R A F 1 / C 5$ were significantly associated with prevalent 
Table 2: Genotype frequencies in rheumatoid arthritis, and in autoantibody-positive/autoantibody-negative rheumatoid arthritis, relative to controls

\begin{tabular}{|c|c|c|c|c|c|c|c|c|c|c|}
\hline RA cohort & $\begin{array}{l}\text { Controls, } \\
n(\%)\end{array}$ & $\begin{array}{l}\text { Cases, } \\
n(\%)\end{array}$ & $\begin{array}{l}\text { Per-allele } \\
\text { OR ( } 95 \% \\
\text { CI) }\end{array}$ & $\begin{array}{l}P \\
\text { trend }\end{array}$ & $\begin{array}{l}\text { Autoanti } \\
\text { body- } \\
\text { positive } \\
\text { RA }\end{array}$ & $\begin{array}{l}\text { Per-allele } \\
\text { OR ( } 95 \% \\
\text { CI) }\end{array}$ & $\begin{array}{l}P \\
\text { trend }\end{array}$ & $\begin{array}{l}\text { Autoanti } \\
\text { body- } \\
\text { negative } \\
\text { RA }\end{array}$ & $\begin{array}{l}\text { Per-allele } \\
\text { OR }(95 \% \\
\text { CI) }\end{array}$ & $\begin{array}{l}P \\
\text { trend }\end{array}$ \\
\hline $\begin{array}{l}\text { HLA-DRB1 } \\
\text { shared epitope }\end{array}$ & $\mathrm{n}=1,351$ & $\mathrm{n}=968$ & & & $n=643$ & & & $\mathrm{n}=298$ & & \\
\hline Negative & $717(53.1)$ & $290(30.0)$ & & & $138(21.5)$ & & & $144(48.3)$ & & \\
\hline One copy & $517(38.3)$ & $475(49.1)$ & $\begin{array}{l}2.12(1.87 \\
\text { to } 2.40)\end{array}$ & $<0.0001$ & 332 (51.6) & $\begin{array}{l}2.85(2.46 \\
\text { to } 3.29)\end{array}$ & $<0.0001$ & $129(43.3)$ & $\begin{array}{l}1.11(0.92 \\
\text { to } 1.35)\end{array}$ & 0.279 \\
\hline $\begin{array}{l}\text { Two } \\
\text { copies }\end{array}$ & $117(8.7)$ & $203(21.0)$ & & & $173(26.9)$ & & & $25(8.4)$ & & \\
\hline $\begin{array}{l}\text { PTPN22 } \\
\text { (rs2476601) }\end{array}$ & $\mathrm{n}=3,492$ & $\mathrm{n}=855$ & & & $\mathrm{n}=572$ & & & $\mathrm{n}=259$ & & \\
\hline GG & 2,817 (80.7) & $624(73.0)$ & & & $413(72.2)$ & & & $195(75.3)$ & & \\
\hline $\mathrm{GA}$ & $635(18.2)$ & $212(24.8)$ & $\begin{array}{l}1.50(1.28 \\
\text { to } 1.75)\end{array}$ & $<0.0001$ & $144(25.2)$ & $\begin{array}{l}1.56(1.31 \\
\text { to } 1.87)\end{array}$ & $<0.0001$ & $60(23.2)$ & $\begin{array}{l}1.32(1.01 \\
\text { to } 1.72)\end{array}$ & 0.039 \\
\hline AA & $40(1.1)$ & $19(2.2)$ & & & $15(2.6)$ & & & $4(1.5)$ & & \\
\hline $\begin{array}{l}\text { OLIG3/TNFAIP3 } \\
\text { (rs6920220) }\end{array}$ & $n=3,478$ & $\mathrm{n}=810$ & & & $\mathrm{n}=545$ & & & $\mathrm{n}=242$ & & \\
\hline GG & $2,146(61.7)$ & $464(57.3)$ & & & $294(53.9)$ & & & $155(64.0)$ & & \\
\hline GA & $1,197(34.4)$ & $303(37.4)$ & $\begin{array}{l}1.19(1.04 \\
\text { to } 1.35)\end{array}$ & 0.009 & $220(40.4)$ & $\begin{array}{l}1.32(1.14 \\
\text { to } 1.54)\end{array}$ & $<0.0001$ & 77 (31.8) & $\begin{array}{l}0.94(0.74 \\
\text { to } 1.18)\end{array}$ & 0.578 \\
\hline $\mathrm{AA}$ & 135 (3.9) & $43(5.3)$ & & & $31(5.7)$ & & & $10(4.1)$ & & \\
\hline $\begin{array}{l}\text { STAT4 } \\
\text { (rs7574865) }\end{array}$ & $n=3,520$ & $n=767$ & & & $\mathrm{n}=515$ & & & $\mathrm{n}=234$ & & \\
\hline GG & $2,151(61.1)$ & $451(58.8)$ & & & $294(57.1)$ & & & $143(61.1)$ & & \\
\hline GT & 1,208 (34.3) & $264(34.4)$ & $\begin{array}{l}1.14(1.00 \\
\text { to } 1.29)\end{array}$ & 0.054 & $190(36.9)$ & $\begin{array}{l}1.17(1.00 \\
\text { to } 1.36)\end{array}$ & 0.048 & 70 (29.9) & $\begin{array}{l}1.13(0.91 \\
\text { to } 1.41)\end{array}$ & 0.266 \\
\hline$\pi$ & $161(4.6)$ & $52(6.8)$ & & & $31(6.0)$ & & & $21(9.0)$ & & \\
\hline $\begin{array}{l}\text { TRAF1/C5 } \\
\text { (rs10760130) }\end{array}$ & $n=3,506$ & $n=763$ & & & $\mathrm{n}=512$ & & & $n=233$ & & \\
\hline$A A$ & $1,096(31.3)$ & $224(29.4)$ & & & $151(29.5)$ & & & 69 (29.6) & & \\
\hline GA & $1,742(49.7)$ & $363(47.6)$ & $\begin{array}{l}1.13(1.01 \\
\text { to } 1.26)\end{array}$ & 0.035 & $238(46.5)$ & $\begin{array}{l}1.15(1.00 \\
\text { to } 1.31)\end{array}$ & 0.043 & $114(48.9)$ & $\begin{array}{l}1.09(0.90 \\
\text { to } 1.31)\end{array}$ & 0.392 \\
\hline GG & $668(19.1)$ & $176(23.1)$ & & & $123(24.0)$ & & & $50(21.5)$ & & \\
\hline
\end{tabular}

$\mathrm{Cl}$, confidence interval; $\mathrm{OR}$, odds ratio; $\mathrm{RA}$, rheumatoid arthritis.

erosions in logistic regression analyses of the total RA cohort, after adjustment for symptom duration (Table 3).

There was also no evidence of association between these five genetic loci with SJC, after adjustment for symptom duration in linear regression analyses of the total RA cohort (Table 3). The TRAF1/C5 locus, however, was significantly associated with $\mathrm{HAQ}$, following adjustment for symptom duration $(P=0.031, \mathrm{n}=468)$. It is important to note that raw $P$ values have been presented throughout. These findings should therefore be considered in light of the number of statistical tests undertaken in the analysis of RA severity, and further larger studies will be required to substantiate these findings. If a strict Bonferroni correction was applied for the severity analyses, the level of significance would be set at $P<0.003$; and for the combined susceptibility and severity studies, the level would be set at $P<0.002$.

\section{Discussion}

In the present study we confirmed that the $H L A-D R B 1$ SE, PTPN22 and the OLIG3/TNFAIP3 and TRAF1/C5 loci were associated with susceptibility to RA in an incep- 
tion cohort. The effect sizes were comparable with the total UKRAG cohort (HLA-DRB1 SE $(2.1,2.6)$, PTPN22 $(1.5,1.5)$, OLIG3/TNFAIP3 $(1.2,1.2)$ and TRAF1/C5 loci $(1.1,1.1)$; early RA compared with total UKRAG cohort $[6-8,14]$, respectively). The distinction between susceptibility and severity remains difficult and some may argue that the present study still does not sample the full spectrum of RA observed in the community. We believe, however, these findings do support a genuine association with RA susceptibility. Further studies utilising communitybased cohorts will ultimately be required to confirm these findings. Of particular interest is the observation that for each of these loci the association was most marked in the autoantibody-positive subgroup and, although the association with STAT4 was not confirmed, some evidence of a weak association was observed in the subgroup harbouring autoantibodies. Indeed, only PTPN22 demonstrated any suggestion of association with RA in the autoantibody-negative cohort, which warrants further investigation in a larger inception cohort.

These findings support the mounting evidence that different genetic loci are associated with autoantibody-positive and autoantibody-negative RA. Many of the genes identified to date may therefore predispose to autoimmunity in general, or more specifically the immunological processes involved in the breakdown of self-tolerance and autoantibody production. This is supported by the association of PTPN22 and the OLIG3/TNFAIP3 locus with other autoantibody-associated autoimmune diseases, such as systemic lupus erythematosus, Graves disease and type 1 diabetes $[5,7,8,15-17]$, but not with those autoimmune/inflammatory disorders not associated with autoantibody production, such as ulcerative colitis, Crohn's disease and ankylosing spondylitis $[5,18,19]$.

The transcription factor encoded by STAT4 is downstream of several cytokines that play a crucial role in the development of Th1 and Th17 responses, such as IL-12, IL-15 and IL-23 [20,21] and the type I interferons [21,22]. Whilst this gene undoubtedly contributes to susceptibility to some autoantibody-associated diseases (RA, systemic lupus erythematosus and type I diabetes), there are recent reports that it may be associated with both clinical forms of inflammatory bowel diseases [23] - suggesting that rather than contributing to autoantibody production, it may be a common risk factor for inflammatory disease per se. This is consistent with the apparent association of STAT4 with both autoantibody-positive and autoantibody-negative RA in the literature $[7,11,15,23]$, although the numbers were considerably lower for the latter subgroup, in all reported series.

Although we acknowledge there was also reduced power to detect trends in the autoantibody-negative cohort in the current study, we were unable to see any suggestive evidence of association with STAT4, with no substantive skewing of allele or genotype frequencies. Additional studies with increased power to investigate autoantibody-negative RA will be needed to unravel the genes predisposing to RA in this patient subgroup. Power calculations based on replicating the association of PTPN22 with autoantibody-negative disease with an effect size in the range 1.2 to 1.5 revealed that 2,909 cases would be required if one control per case was used, reducing to 2,169 if two controls per case were used. If all five loci were investigated, the number of autoantibodynegative cases required would need to increase to 4,329 and 3,227, respectively - with $\sim 12,000$ cases required if the effect size was reduced to 1.1. Such studies will require a concerted international effort and large-scale recruitment of cases from around the globe.

In the current study, we analysed the SNPs displaying the strongest association with RA, after the strongly associated HLA-DRB1 SE alleles, in the UK Caucasian population [24]. To date, there have been relatively few genetic loci that have shown consistent association with disease severity in RA. As stated previously, it is very difficult to tease out the influence of drugs and other nongenetic factors when designing these studies. We therefore chose to investigate these susceptibility loci with objective markers of joint inflammation or disease severity (radiographic erosions, SJC, and HAQ) at presentation to the rheumatology department. The presence of radiographic articular erosions is generally accepted as the most objective measure of articular damage that is accessible for all rheumatologists, but there is currently a paucity of studies investigating this early time point.

In this exploratory study we were unable to find any strong evidence that these five susceptibility genes were associated with disease severity measures at baseline. We found some weak evidence to support the association of the TRAF1/C5 locus with HAQ at baseline, a marker of function, although this would not remain significant after correction for multiple comparisons. Carriers of the minor A allele of rs10818488 at this locus were previously shown to have increased radiographic progression, albeit in a small cohort of 278 CCP-positive individuals [25], whereas homozygosity for the $\mathrm{G}$ allele may be associated with mortality [26]. We found no evidence, however, that TRAF1/C5 was associated with erosions in this cohort. It is important to note that due to a high level of linkage disequilibrium between the genes encoding TNF receptorassociated factor 1 and complement component 5 , it is currently not possible to unravel which of these two genes at $9 \mathrm{q} 33.2$ harbours the causal variant. Both are excellent candidate genes that may perpetuate chronic inflammation in RA. TNF receptor-associated factor 1 is a negative regulator of TNF receptor and Toll-like receptor signalling, and may contribute to the proliferation of $\mathrm{T}$ cells, and the complement pathway may directly con- 
Table 3: Association with disease severity measures in early rheumatoid arthritis and in autoantibody-positive/antibodynegative disease

\begin{tabular}{|c|c|c|c|c|c|c|c|c|c|}
\hline \multirow[t]{2}{*}{ RA cohort } & \multicolumn{3}{|c|}{ Erosions } & \multicolumn{3}{|c|}{ Swollen joint count } & \multicolumn{3}{|c|}{ Health Assessment Questionnaire } \\
\hline & $\begin{array}{l}\text { Erosive, } \\
n(\%)\end{array}$ & $\begin{array}{l}\text { Per-allele } \\
\text { OR (95\% } \\
\text { CI) }\end{array}$ & $\begin{array}{l}P \text { trend } \\
\text { adj. }^{a}\end{array}$ & $\begin{array}{l}\text { Mean } \\
(95 \% \mathrm{Cl})\end{array}$ & $\begin{array}{l}\text { Coefficient } \\
(95 \% \mathrm{Cl})\end{array}$ & $\begin{array}{l}P \text { trend } \\
\text { adj. }^{a}\end{array}$ & $\begin{array}{l}\text { Mean } \\
(95 \% \mathrm{CI})\end{array}$ & $\begin{array}{l}\text { Coefficient } \\
(95 \% \mathrm{CI})\end{array}$ & $\begin{array}{l}P \text { trend } \\
\text { adj. }{ }^{a}\end{array}$ \\
\hline $\begin{array}{l}\text { HLA-DRB1 } \\
\text { shared epitope }\end{array}$ & $554(21.5)$ & & & $\mathrm{n}=587$ & & & $\mathrm{n}=587$ & & \\
\hline Negative & $175(22.9)$ & 0.88 & 0.398 & $\begin{array}{l}10.5 \text { (9.5 to } \\
11.5)\end{array}$ & -0.03 & 0.455 & $\begin{array}{l}1.35 \text { (1.24 to } \\
1.47)\end{array}$ & -0.00 & 0.965 \\
\hline One copy & $278(20.9)$ & $\begin{array}{l}\text { (0.65 to } \\
1.19)\end{array}$ & & $\begin{array}{l}9.4(8.7 \text { to } \\
10.1)\end{array}$ & $\begin{array}{l}(-1.04 \text { to } \\
0.47)\end{array}$ & & $\begin{array}{l}1.38 \text { (1.29 to } \\
1.46)\end{array}$ & $\begin{array}{l}(-0.09 \text { to } \\
0.09)\end{array}$ & \\
\hline $\begin{array}{l}\text { Two } \\
\text { copies }\end{array}$ & $101(20.8)$ & & & $\begin{array}{l}9.7 \text { ( } 8.4 \text { to } \\
11.0)\end{array}$ & & & $\begin{array}{l}1.27 \text { ( } 1.14 \text { to } \\
1.41)\end{array}$ & & \\
\hline $\begin{array}{l}\text { PTPN22 } \\
\text { (rs2476601) }\end{array}$ & $580(20.7)$ & & & $n=468$ & & & $\mathrm{n}=468$ & & \\
\hline GG & $423(22.0)$ & 0.75 & 0.189 & $\begin{array}{l}9.5(8.8 \text { to } \\
10.2)\end{array}$ & -0.02 & 0.593 & $\begin{array}{l}1.32 \text { (1.23 to } \\
1.40)\end{array}$ & 0.06 & 0.133 \\
\hline GA & $147(17.0)$ & $\begin{array}{l}\text { (0.48 to } \\
1.16)\end{array}$ & & $\begin{array}{l}9.0(7.8 \text { to } \\
10.1)\end{array}$ & $\begin{array}{l}(-1.31 \text { to } \\
0.75)\end{array}$ & & $\begin{array}{l}1.43(1.30 \text { to } \\
1.56)\end{array}$ & $\begin{array}{l}(-0.03 \text { to } \\
0.21)\end{array}$ & \\
\hline AA & $10(20.0)$ & & & $\begin{array}{l}10.4 \text { ( } 1.9 \text { to } \\
18.9 \text { ) }\end{array}$ & & & $\begin{array}{l}1.48 \text { ( } 0.35 \text { to } \\
2.61)\end{array}$ & & \\
\hline $\begin{array}{l}\text { OLIG3/TNFAIP3 } \\
\text { (rs6920220) }\end{array}$ & $551(20.3)$ & & & $n=468$ & & & $\mathrm{n}=468$ & & \\
\hline GG & $302(19.9)$ & 1.03 & 0.853 & $\begin{array}{l}9.4 \text { (8.6 to } \\
10.1)\end{array}$ & 0.04 & 0.291 & $\begin{array}{l}1.36 \text { (1.27 to } \\
1.45)\end{array}$ & -0.01 & 0.880 \\
\hline GA & $217(20.7)$ & $\begin{array}{l}(0.73 \text { to } \\
1.46)\end{array}$ & & $\begin{array}{l}9.3(8.3 \text { to } \\
10.2)\end{array}$ & $\begin{array}{l}(-0.39 \text { to } \\
1.31)\end{array}$ & & $\begin{array}{l}1.36 \text { (1.24 to } \\
1.48)\end{array}$ & $\begin{array}{l}(-0.11 \text { to } \\
0.09)\end{array}$ & \\
\hline AA & $32(21.9)$ & & & $\begin{array}{l}10.5 \text { (7.7 to } \\
13.3)\end{array}$ & & & $\begin{array}{l}1.07 \text { (0.76 to } \\
1.37 \text { ) }\end{array}$ & & \\
\hline $\begin{array}{l}\text { STAT4 } \\
\text { (rs7574865) }\end{array}$ & $476(20.4)$ & & & $n=468$ & & & $n=468$ & & \\
\hline GG & $271(22.1)$ & 0.82 & 0.291 & $\begin{array}{l}9.5(8.7 \text { to } \\
10.2)\end{array}$ & 0.01 & 0.873 & $\begin{array}{l}1.38 \text { (1.28 to } \\
1.47)\end{array}$ & -0.06 & 0.193 \\
\hline GT/ & $170(18.2)$ & $\begin{array}{l}(0.57 \text { to } \\
1.19)\end{array}$ & & $\begin{array}{l}9.3(8.2 \text { to } \\
10.3)\end{array}$ & $\begin{array}{l}(-0.82 \text { to } \\
0.97)\end{array}$ & & $\begin{array}{l}1.35 \text { (1.23 to } \\
1.46)\end{array}$ & $\begin{array}{l}(-0.17 \text { to } \\
0.04)\end{array}$ & \\
\hline$\pi$ & $35(17.1)$ & & & $\begin{array}{l}9.5(7.0 \text { to } \\
12.0)\end{array}$ & & & $\begin{array}{l}1.12 \text { ( } 0.85 \text { to } \\
1.39)\end{array}$ & & \\
\hline $\begin{array}{l}\text { TRAF1/C5 } \\
\text { (rs10760130) }\end{array}$ & $474(20.3)$ & & & $n=468$ & & & $\mathrm{n}=468$ & & \\
\hline AA & $140(16.4)$ & $\begin{array}{l}1.18(0.86 \\
\text { to } 1.61)\end{array}$ & 0.311 & $\begin{array}{l}9.7(8.6 \text { to } \\
10.8)\end{array}$ & -0.03 & 0.502 & $\begin{array}{l}1.25 \text { ( } 1.11 \text { to } \\
1.38)\end{array}$ & 0.09 & 0.031 \\
\hline $\mathrm{GA}$ & $225(22.7)$ & & & $\begin{array}{l}9.1 \text { (8.3 to } \\
9.9)\end{array}$ & $\begin{array}{l}(-1.07 \text { to } \\
0.52)\end{array}$ & & $\begin{array}{l}1.34 \text { (1.24 to } \\
1.43)\end{array}$ & $\begin{array}{l}(0.01 \text { to } \\
0.19)\end{array}$ & \\
\hline GG & $109(20.2)$ & & & $\begin{array}{l}9.6(8.4 \text { to } \\
10.8)\end{array}$ & & & $\begin{array}{l}1.50 \text { ( } 1.35 \text { to } \\
1.65)\end{array}$ & & \\
\hline
\end{tabular}

$\mathrm{Cl}$, confidence interval; $\mathrm{OR}$, odds ratio; $\mathrm{RA}$, rheumatoid arthritis. aAdjusted for symptom duration (all cases having a symptom duration $<24$ months). 
tribute to immune complex-mediated inflammation $[25,27]$. Intensive resequencing efforts with additional fine-mapping studies in expanded genetic cohorts are currently underway to identify the disease-associated variant at such loci. It is likely that for those loci with very strong and extensive linkage disequilibrium, however, functional studies may ultimately be required to unravel the biological significance of the genetic findings.

\section{Conclusions}

The importance of studying inception cohorts cannot be underestimated since most hospital-based cohorts represent the severe end of the RA spectrum and genetic associations derived from such patients cannot discriminate between susceptibility and severity factors. The present study supports an association between HLA-DRB1 SE alleles, PTPN22, OLIG3/TNFAIP3, STAT4 and TRAF1/ C5 with susceptibility to autoantibody-positive RA, but only the TRAF1/C5 locus was associated with disease severity in this cohort, although this would no longer remain significant after correction for multiple comparisons. Substantially larger cohorts will ultimately be required to have adequate power to investigate clinical, immunological and genetic factors determining disease severity and response to therapy, and we hope these data will assist future power calculations. Although the ultimate goal is the development of clinical algorithms that will facilitate personalised medicine, it also remains important to identify the immunological and biochemical pathways that determine outcome, which can then be targeted therapeutically. The TRAF1/C5 locus in particular warrants further investigation as a potential disease severity locus in RA.

\section{Authors' information}

Membership of the YEAR Consortium.

Management team: Paul Emery, Philip Conaghan, Ann Morgan, Anne-Maree Keenan, Elizabeth Hensor and Julie Kitcheman at the Section of Musculoskeletal Disease, Leeds Institute of Molecular Medicine, University of Leeds, UK. Mark Quinn at York District Hospital, York, UK.

Consultants: Gareth Huston, Mike Martin, Colin Pease and Sally Cox at the Section of Musculoskeletal Disease, Leeds Institute of Molecular Medicine, University of Leeds, UK. Michael Green and Amanda Isdale at York District Hospital, York, UK. Andrew Gough and Michael Green at Harrogate District Hospital, Harrogate, UK. Richard Reece at the Huddersfield Royal Infirmary, Huddersfield, UK. Lesley Hordon at Dewsbury District and General Hospital, Dewsbury, UK. Philip Helliwell and Richard Melsom at St Luke's Hospital, Bradford, UK. Sheelagh Doherty at Hull Royal Infirmary, Hull, UK. Ade Adebajo at Barnsley District General Hospital, Barnsley,
UK. Andrew Harvey, Steve Jarrett and Zunaid Karim at Pinderfields General Hospital, Wakefield, UK. Dennis McGonagle at Calderdale Royal Hospital, Halifax, UK.

SpRs: Victoria Bejarano and Jackie Nam at the Section of Musculoskeletal Disease, Leeds Institute of Molecular Medicine, University of Leeds, UK.

Nurses: Claire Brown, Christine Thomas, David Pickles, Alison Hammond, Belinda Rhys-Evans, Barbara Padwell, Sally Smith and Heather King at the Section of Musculoskeletal Disease, Leeds Institute of Molecular Medicine, University of Leeds, UK. Anne Gill and Julie Green at York District Hospital, York, UK. Beverley Neville at Harrogate District Hospital, Harrogate, UK. Alan Fairclough and Caroline Nunns at Huddersfield Royal Infirmary, Huddersfield, UK. Jill Firth and Linda Sigsworth at St Luke's Hospital, Bradford, UK. Jayne Heard at Hull Royal Infirmary, Hull, UK. Julie Madden and Lynda Taylor at Calderdale Royal Hospital, Halifax, UK.

Laboratory staff: Diane Corscadden, Karen Henshaw, Lubna-Haroon Rashid, Stephen G Martin and James I Robinson at the Section of Musculoskeletal Disease, Leeds Institute of Molecular Medicine, University of Leeds, UK.

\section{Membership of the UKRAG Consortium.}

University of Manchester: Stephen Eyre, Anne Hinks, Laura J Gibbons, John Bowes, Edward Flynn, Paul Martin, Wendy Thomson, Anne Barton and Jane Worthington at the arc-Epidemiology Unit, The University of Manchester, UK.

University of Leeds: The YEAR consortium, Stephen Martin, James I Robinson, Ann W Morgan and Paul Emery at the Leeds Institute of Molecular Medicine, Section of Musculoskeletal Disease, University of Leeds, UK.

University of Sheffield: Anthony G Wilson at the School of Medicine \& Biomedical Sciences, The University of Sheffield, UK.

University of London: Sophia Steer at the Clinical and Academic Rheumatology, Kings College Hospital NHS Foundation Trust, London, UK.

University of Aberdeen: Lynne Hocking and David M Reid at the Bone Research Group, Department of Medicine \& Therapeutics, University of Aberdeen, UK.

University of Oxford: Pille Harrison and Paul Wordsworth at University of Oxford Institute of Musculoskeletal Sciences, Oxford, UK.

\section{Abbreviations}

CCP: cyclic citrullinated peptide; HAQ: Health Assessment Questionnaire; IL: interleukin; OR: odds ratio; PCR: polymerase chain reaction; RA: rheumatoid arthritis; RF: rheumatoid factor; SE: shared epitope; SJC: swollen joint count; SNP: single nucleotide polymorphisms; STAT: signal transducer and activator of transcription; Th: T-helper cell; TNF: tumour necrosis factor; UKRAG: UK Rheumatoid Arthritis Genetics; YEAR: Yorkshire Early Arthritis Register.

\section{Competing interests}

LS and HAE are employed by Roche Molecular Systems, Inc. (Pleasanton, CA USA), provider of HLA-DRB1 and PTPN22 genotyping reagents for a subgroup of 
subjects analysed in the present study. Otherwise the authors declare that they have no competing interests.

\section{Authors' contributions}

AWM conceived and designed this study, contributed to the acquisition of data, undertook the statistical analyses, interpreted the data and wrote the manuscript. JIR contributed to the acquisition of data and drafted part of the manuscript. PGC contributed to the acquisition of data and critically reviewed the manuscript. SGM contributed to the acquisition of data and critically reviewed the manuscript. The YEAR Consortium contributed to the acquisition of data. EMAH contributed to the statistical analysis and critically reviewed the manuscript. MDM drafted part of the manuscript. LS developed the multilocus SNP genotyping platform and critically reviewed the manuscript. HAE developed the multi-locus HLA-DRB1 genotyping platform and critically reviewed the manuscript. $\mathrm{H}-\mathrm{CG}$ contributed to the acquisition of data and critically reviewed the manuscript. $A B$ contributed to the acquisition of data and critically reviewed the manuscript. The UKRAG Consortium contributed to the acquisition of data and critically reviewed the manuscript. JW contributed to the acquisition of data and critically reviewed the manuscript. PE contributed to the acquisition of data and critically reviewed the manuscript.

\section{Acknowledgements}

The authors would like to acknowledge the statistical advice provided by Dr Jenny Barrett and her thoughtful review of the manuscript. They thank the Arthritis Research Campaign for their support (grant reference numbers 17552, E0555 and 18066). The authors would also like to acknowledge the NIHR Leeds Musculoskeletal Biomedical Research Unit, Leeds Teaching Hospitals Charitable Trustees, and NHS Research and Development Support Fund for Guy's and St Thomas' and Lewisham NHS Trusts. They acknowledge use of DNA from the British 1958 Birth Cohort collection, funded by the Medical Research Council grant G0000934 and the Wellcome Trust grant 068545/Z/02.

\section{Author Details}

${ }_{1}^{1} \mathrm{NIHR}$ - Leeds Musculoskeletal Biomedical Research Unit, Leeds Institute of Molecular Medicine, University of Leeds, Chapel Allerton Hospital, Chapeltown Road, Leeds LS7 4SA, UK, ${ }^{2}$ Roche Molecular Systems, 4300 Hacienda Drive, Pleasanton, CA 94588-8566, USA, ${ }^{3}$ Clinical Immunology, St James's University Hospital, Beckett Street, Leeds LS97TF, UK and 4arc-Epidemiology Unit, Stopford Building, The University of Manchester, Oxford Road, Manchester M13 9PT, UK

Received: 27 August 2009 Revised: 27 January 2010 Accepted: 30 March 2010 Published: 30 March 2010

\section{References}

1. Symmons D, Turner G, Webb R, Asten P, Barrett E, Lunt M, Scott D, Silman $A$ : The prevalence of rheumatoid arthritis in the United Kingdom: new estimates for a new century. Rheumatology (Oxford) 2002, 41:793-800.

2. MacGregor AJ, Snieder H, Rigby AS, Koskenvuo M, Kaprio J, Aho K, Silman $\mathrm{AJ}$ : Characterizing the quantitative genetic contribution to rheumatoid arthritis using data from twins. Arthritis Rheum 2000, 43:30-37.

3. MacKay K, Eyre S, Myerscough A, Milicic A, Barton A, Laval S, Barrett J, Lee D, White S, John S, MacKay K, Eyre S, Myerscough A, Milicic A, Barton A, Laval S, Barrett J, Lee D, White S, John S, Brown MA, Bell J, Silman A, Ollier W, Wordsworth P, Worthington J: Whole-genome linkage analysis of rheumatoid arthritis susceptibility loci in 252 affected sibling pairs in the United Kingdom. Arthritis Rheum 2002, 46:632-639.

4. Lee YH, Rho YH, Choi SJ, Ji JD, Song GG, Nath SK, Harley JB: The PTPN22 C1858T functional polymorphism and autoimmune diseases - a metaanalysis. Rheumatology (Oxford) 2007, 46:49-56.

5. Xavier RJ, Rioux JD: Genome-wide association studies: a new window into immune-mediated diseases. Nat Rev Immunol 2008, 8:631-643.

6. The Wellcome Trust Case Control Consortium: Genome-wide association study of 14,000 cases of seven common diseases and 3,000 shared controls. Nature 2007, 447:661-678.

7. Barton A, Thomson W, Ke X, Eyre S, Hinks A, Bowes J, Gibbons L, Plant D, Wellcome Trust Case Control Consortium, Wilson AG, Barton A, Thomson W, Ke X, Eyre S, Hinks A, Bowes J, Gibbons L, Plant D, Wellcome Trust Case Control Consortium, Wilson AG, Marinou I, Morgan AW, Emery P, YEAR consortium, Steer S, Hocking L, Reid DM, Wordsworth P, Harrison P, Worthington $\mathrm{J}$ : Re-evaluation of putative rheumatoid arthritis susceptibility genes in the post-genome wide association study era and hypothesis of a key pathway underlying susceptibility. Hum Mol Genet 2008, 17:2274-2279.

8. Thomson W, Barton A, Ke X, Eyre S, Hinks A, Bowes J, Donn R, Symmons D, Hider S, Bruce IN, Thomson W, Barton A, Ke X, Eyre S, Hinks A, Bowes J, Donn R, Symmons D, Hider S, Bruce IN, Wellcome Trust Case Control Consortium, Wilson AG, Marinou I, Morgan A, Emery P, YEAR consortium, Carter A, Steer S, Hocking L, Reid DM, Wordsworth P, Harrison P, Strachan D, Worthington J: Rheumatoid arthritis association at 6q23. Nat Genet 2007, 39:1431-1433.

9. Bowes J, Barton A: Recent advances in the genetics of RA susceptibility. Rheumatology (Oxford) 2008, 47:399-402.

10. Helm-van Mil AHM van der, Huizinga TWJ: Advances in the genetics of rheumatoid arthritis point to subclassification into distinct disease subsets. Arthritis Res Ther 2008, 10:205.

11. Lee HS, Remmers EF, Le JM, Kastner DL, Bae SC, Gregersen PK: Association of STAT4 with rheumatoid arthritis in the Korean population. Arthritis Rheum 2008, 58:2598-2602.

12. Kobayashi S, Ikari K, Kaneko H, Kochi Y, Yamamoto K, Shimane K, Nakamura Y, Toyama Y, Mochizuki T, Tsukahara S, Kawaguchi Y, Terai C, Hara M, Tomatsu T, Yamanaka H, Horiuchi T, Tao K, Yasutomo K, Hamada D, Yasui N, Inoue H, Itakura M, Okamoto H, Kamatani N, Momohara S: Association of STAT4 with susceptibility to rheumatoid arthritis and systemic lupus erythematosus in the Japanese population. Arthritis Rheum 2008, 58:1940-1946.

13. Arnett FC, Edworthy SM, Bloch DA, McShane DJ, Fries JF, Cooper NS, Healey LA, Kaplan SR, Liang MH, Luthra HS, Arnett FC, Edworth SM, Bloch DA, McShane DJ, Fries JF, Cooper NS, Healey LA, Kaplan SR, Liang MH, Luthra HS, Medsger TA Jr, Mitchell DM, Neustadt DH, Pinals RS, Schaller JG, Sharp JT, Wilder RL, Hunder GG: The American-Rheumatism-Association 1987 revised criteria for the classification of rheumatoid-arthritis. Arthritis Rheum 1988, 31:315-324.

14. Morgan AW, Thompson W, Martin SG, YEAR consortium, Carter AM, UKRAG Consortium, Erlich HA, Barton A, Hocking L, Reid DM, Morgan AW, Thompson W, Martin SG, YEAR consortium, Carter AM, UKRAG Consortium, Erlich HA, Barton A, Hocking L, Reid DM, Harrison P, Wordsworth BP, Steer S, Worthington J, Emery P, Wilson AG, Barrett JH: Re-evaluation of the interaction between HLA-DRB1 SE alleles, PTPN22 and smoking in determining the susceptibility to autoantibody positive and negative rheumatoid arthritis in a large UK Caucasian population. Arthritis Rheum 2009, 60:2565-2576.

15. Remmers EF, Plenge RM, Lee AT, Graham RR, Hom G, Behrens TW, de Bakker PI, Le JM, Lee HS, Batliwalla F, Li W, Masters SL, Booty MG, Carulli JP, Padyukov L, Alfredsson L, Klareskog L, Chen WV, Amos Cl, Criswell LA, Seldin MF, Kastner DL, Gregersen PK: STAT4 and the risk of rheumatoid arthritis and systemic lupus erythematosus. N Engl J Med 2007, 357:977-986.

16. Graham RR, Cotsapas C, Davies L, Hackett R, Lessard CJ, Leon JM, Burtt NP, Guiducci C, Parkin M, Gates C, Plenge RM, Behrens TW, Wither JE, Rioux JD, Fortin PR, Graham DC, Wong AK, Vyse TJ, Daly MJ, Altshuler D, Moser KL, Gaffney PM: Genetic variants near TNFAIP3 on 6q23 are associated with systemic lupus erythematosus. Nat Genet 2008, 40:1059-1061.

17. Musone SL, Taylor KE, Lu TT, Nititham J, Ferreira RC, Ortmann W, Shifrin N, Petri MA, Kamboh MI, Manzi S, Seldin MF, Gregersen PK, Behrens TW, Ma A, Kwok PY, Criswell LA: Multiple polymorphisms in the TNFAIP3 region are independently associated with systemic lupus erythematosus. Nat Genet 2008, 40:1062-1064

18. Wellcome Trust Case Control Consortium, The Australo-Anglo-American Spondilitis Consortium: Association scan of 14,500 nonsynonymous SNPs in four disease identifies autoimmunity variants. Nat Genet 2007, 39:1329-1337.

19. Barrett JC, Hansoul S, Nicolae DL, Cho JH, Duerr RH, Rioux JD, Brant SR, Silverberg MS, Taylor KD, Barmada MM, Barrett JC, Hansoul S, Nicolae DL, Cho JH, Duerr RH, Rioux JD, Brant SR, Silverberg MS, Taylor KD, Barmada MM, Bitton A, Dassopoulos T, Datta LW, Green T, Griffiths AM, Kistner EO, Murtha MT, Regueiro MD, Rotter Jl, Schumm LP, Steinhart AH, Targan SR, Xavier RJ, Libioulle C, Sandor C, Lathrop M, Belaiche J, Dewit O, Gut I, Heath S, et al:: Genome-wide association defines more than 30 distinct susceptibility loci for Crohn's disease. Nat Genet 2008, 40:955-962.

20. Kaplan M: STAT4: a critical regulator of inflammation in vivo. Immunol Res 2005, 31:231-242. 
21. Mathur AN, Chang HC, Zisoulis DG, Stritesky GL, Yu Q, O'Malley JT, Kapur R, Levy DE, Kansas GS, Kaplan MH: Stat3 and Stat4 direct development of IL-17-secreting Th cells. J Immunol 2007, 178:4901-4907.

22. Kariuki SN, Kirou KA, MacDermott EJ, Barillas-Arias L, Crow MK, Niewold TB: Cutting edge: autoimmune disease rsk variant of STAT4 confers increased sensitivity to IFN-a in lupus patients in vivo. J Immunol 2009, 182:34-38.

23. Martínez A, Varadé J, Márquez A, Cénit MC, Espino L, Perdigones N, Santiago JL, Fernández-Arquero M, de la Calle H, Arroyo R, Mendoza JL, Fernández-Gutiérrez B, de la Concha EG, Urcelay E: Association of the STAT4 gene with increased susceptibility for some immune-mediated diseases. Arthritis Rheum 2008, 58:2598-2602.

24. Naseem H, Thomson W, Silman A, Worthington J, Barton A: The PTPN22* ${ }^{*} 1858 \mathrm{~T}$ functional polymorphism is associated with susceptibility to inflammatory polyarthritis but neither this nor other variants spanning the gene is associated with disease outcome. Ann Rheum Dis 2008, 67:251-255.

25. Kurreeman FA, Padyukov L, Marques RB, Schrodi SJ, Seddighzadeh M, Stoeken-Rijsbergen G, Helm-van Mil AH van der, Allaart CF, Verduyn W, Houwing-Duistermaat J, Alfredsson L, Begovich AB, Klareskog L, Huizinga TW, Toes RE: A candidate gene approach identifies the TRAF1/C5 region as a risk factor for rheumatoid arthritis. PLoS Med 2007, 4:e278.

26. Panoulas VF, Smith JP, Nightingale P, Kitas GD: Association of the TRAF1/ C5 locus with increased mortality, particularly from malignancy or sepsis, in patients with rheumatoid arthritis. Arthritis Rheum 2009, 60:39-46.

27. Plenge RM, Seielstad M, Padyukov L, Lee AT, Remmers EF, Ding B, Liew A, Khalili H, Chandrasekaran A, Davies LR, Li W, Tan AK, Bonnard C, Ong RT, Thalamuthu A, Pettersson S, Liu C, Tian C, Chen WV, Carulli JP, Beckman EM, Altshuler D, Alfredsson L, Criswell LA, Amos Cl, Seldin MF, Kastner DL, Klareskog L, Gregersen PK: TRAF1-C5 as a risk locus for rheumatoid arthritis - a genomewide study. N Engl J Med 2007, 357:1 199-1209.

doi: 10.1186/ar2969

Cite this article as: Morgan et al., Evaluation of the rheumatoid arthritis susceptibility loci HLA-DRB1, PTPN22, OLIG3/TNFAIP3, STAT4 and TRAF1/C5 in an inception cohort Arthritis Research \& Therapy 2010, 12:R57

Submit your next manuscript to BioMed Centra and take full advantage of:

- Convenient online submission

- Thorough peer review

- No space constraints or color figure charges

- Immediate publication on acceptance

- Inclusion in PubMed, CAS, Scopus and Google Scholar

- Research which is freely available for redistribution

Submit your manuscript at www.biomedcentral.com/submit
C) Biomed Central 